\title{
LIST UF
}

\section{STANDARD BRED HORSES}

\author{
OFFERED FOR SALE BY
}

\section{F. Osborne, Nowedonah Stock Farm,} WATER MILL, SUFFOLK CO, N, Y,

\section{SPRING, 1889}




\section{No. 1.}

NARTICA, b. m., foaled I 876 ; bred by Chas. Backman, Stony Ford, N. Y. Sire, Messenger Duroc. First dam Mineola by Rysdyk's Hambletonian. Second dam Lady Banker by Roe's Abdallah Chief. Third dam by Saltram. Rysdyk's Hambletoni n by Abdallah, son of Mambrino. First dam Charles Kent mare. by Imp. Bellfounder. Second dam One Eye, by Bishop's Hambletonian. Third dam Silvertail, by Imp. Messenger.

Roe's Abdallah Chief by Abdallah, son of Marnbrino. First dam by Phillip, son of Duroc. Second dam by Decatur, son of Henry Saltram by Weber's Kentucky Whip First dam by Sea Gull, son of Duroc. Standard and registered

DesCRIPTION.-Bay ; I5.2 ; broken single nnd dorble by Carll Burr, of Comac, L I. A good, prompt driver ; p $\lrcorner$ rfect disposition and good producer. Possessing, as she does, the blood of Hambletonian through her sire and dam, gives her great value as a brood mare.

\section{No. 2.}

FANNY G., (standard) b. m, I884; sire Comac. First dam Nartica by Messenger Duroc (see No. I) sire of Elaine 2.20; Prospero 220 ; Charley Champlin, Dame Trot, and fourteen others in the 30 list.

Comac by Kentucky Prince, sire of Guy 2.12; Spofford 2. I $8 \frac{3}{4}$; Company 2. $19 \frac{3}{4}$; Fred Folger 2.20 $\frac{1}{4}$, and seven others in the 30 list. Also sire of Ken-

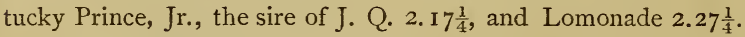

Comac's dam Atlanta, by Messenger Duroc. Second dam Flora Gardner, dam of Guy 2.12, Fred Folger $220 \frac{1}{4}$, by Seeley's American Star. Sire of forty dams that have produced 2.30 trotters. Third dam by Bay Richmond. Fnurth dam by Diamond, son of American Eclipse.

Description.-Fanny $G$ is dark bay, full Ió hands, broken single and double ; never trained ; shows a long, frictionless gait, that should carry her fast. In foal to Red Cross ; record $221 \frac{1}{2}$. 


\title{
LIST UF
}

\section{STANDARD BRED HORSES}

\author{
OFFERED FOR SALE BY
}

D. F. Osborne, Nowedonah Stock Farm, WATER MILL, SUFFOLK CO, N, Y,

\section{SPRING, 1889}




\section{No. 1.}

NARTICA, b. m, foaled I 876 ; bred by Chas. Backman, Stony Ford, N. Y. Sire, Messenger Duroc. First dam Mineola by Rysdyk's Hambletonian. Second dam Lady Banker by Roe's Abdallah Chief. Third dam by Saltram. Rysdyk's Hambletoni n by Abdallah, son of Mambrino. First dam Charles Kent mare, by Imr. Bellfounder. Second dam One Eye, by Bishop's Hambletonian. Third dam Silvertail, by Imp. Messenger.

Roe's Abdall th Chief by Abdallah, son of Mambrino, First dam by Phillip, son of Duroc. Second dam by Decatur, son of Henry Saltram by Weber's Kentucky Whip First dam by Sea Gull, son of Duroc. Standard and registered

Desckiption.-Bay ; 15.2; broken single nnd do'tble by Carll Burr, of Comac, L I. A good, prompt driver ; p $\rightarrow$ rfect disposition and good producer. Possessing, as she does, the blood of Hambletonian through her sire and dam, gives her great value as a brood mare.

\section{No. 2.}

FANNY G., (standard) b. m, 1884; sire Comac. First dam Nartica by Messenger Duroc (see No. I) sire of Elaine 2.20 ; Prospero 220 ; Charley Champlin, Dame Trot, and fourteen others in the 30 list.

Comac by Kentucky Prince, sire of Guy 2.12; Spofford 2. I8 $\frac{3}{4}$; CompanY 2. I $9 \frac{3}{4}$; Fred Folger 2.20 $\frac{1}{4}$, and seven others in the 30 list. Also sire of Kentucky Prince, Jr., the sire of J. Q. 2. $17 \frac{1}{4}$, and Lomonade $2.27 \frac{1}{4}$.

Comac's dam Atlanta, by Messenger Duroc. Second dam Flora Gardner, dam of Guy 2.12, Fred Folger $220 \frac{1}{4}$, by Seeley's American Star. Sire of forty dams that have produced 2.30 trotters. Third dam by Bay Richmond. Fnurth dam by Diamond, son of American Eclipse.

Description.-Fanny $G$ is dark bay, full ió hands, broken single and double ; never trained; shows a long, frictionless gait, that should carry her fast. In foal to Red Cross ; record $221 \frac{1}{2}$. 


$$
\text { .Vo. } 3 \text {. }
$$

BLANCHE, (standard) b m., I855, by Comac. Full sister to Fanny G (see No. 2). Blanche is blood-bay, about $\mathbf{I}_{5}$ 2, elegant form, good disposition, being prompt an ? energetic, yet wonderfully kind. Broken single and double, shows a fine turn of speed for her chance, has the low, stealing gait peculiar to Guy, and judging from present appearances will trot very fast. (Can be seen at the Locust Grove Training Stables, Jed. Williamson, Prop'r., Stony Brook, L. I.

$$
\text { No. } 4 \text {. }
$$

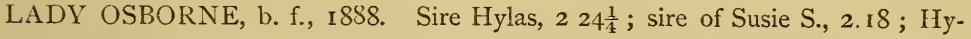

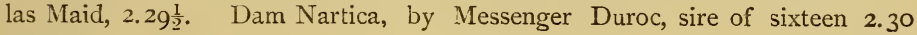
trotters.

Hylas by Alcalde, by Mambrino Chief, by Mambrino Paymaster. First dam Santa Míaria, by Pilot, Jr. ; Alcalde's dam by Pilot, Jr.

Description.-Lady Osborne is a beautifully-formed filly, and possessing, as see does, the blood of Pilot, Jr., through her sire and grand-dam, and the blood of Hambletonian through her dam and grand-dam, she ought to be valuable as a brood mare. Trots fast at the halter.

$$
\text { No. } 5 \text {. }
$$

FLYING POINT, b. g.. I 886 . by Ilylas; secord, $224 \frac{1}{2}$, made in a sixth heat at six years, in a hot race, on a heavy track. Hylas' early life was passed in obscurity, having had no opportunity in the stud until brought to Long Island by Mr. 11. L Fleet, where, under favoring circumstances, he has demonstrated his ability to fix his characteristics. His stock are very young, but many of them, although out of mares of indifferent breeding, show wonderful flights of speed.

Flying Point's dam Fanny White, by Fleetwing, by Black Eagle. Second dam Fanny, by a son o! Montauk, by Cassius M. Clay. 
Digitized by the Internet Archive in 2009 with funding from

Boston Library Consortium Member Libraries 


\section{Vo. 3.}

BLANCHE, (standard) b m., 1855, by Comac. Full sister to Fanny G (see No. 2). Blanche is blood-bay, about ${ }_{5} 5$ 2, elegant form, good disposition, being prompt an energetic, yet wonderfully kind. Broken single and double, shows a fine turn of speed for her chance, has the low, stealing gait peculiar to Guy, and judging from present appearances will trot very fast. (Can be seen at the Locust Grove Training Stables, Jed. Williamson, Prop'r., Stony Brook, L. I.

\section{No. 4 .}

LADY OSBORNE, b. f., I888. Sire Hylas, $224 \frac{1}{4}$; sire of Susie S., 2.18 ; Hy-

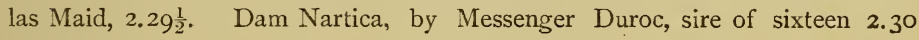
trotters.

Hylas by Alcalde, by Mambrino Chief, by Mambrino Paymaster. First dam Santa Maria, by Pilot, Jr. ; Alcalde's dam by Pilot, Jr.

Description. - Lady Osborne is a beautifully-formed filly, and possessing, as see does, the blood of Pilot, Jr., through her sire and grand-dam, and the blood of Hambletonian through her dam and grand-dam, she ought to be valuable as a brood mare. Trots fast at the halter.

\section{No. 5.}

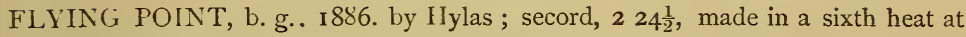
six years, in a hot race, on a heavy track. Hylas' early life was passed in obscurity, having had no opportunity in the stud until brought to Long Island by Mr. II. L Fleet, where, under favoring circumstances, he has demonstrated his ability to fix his characteristics. His stock are very young, but many of them, although out of mares of indifferent breeding, show wonderful flights of speed.

Flying Point's dam Fanny White, by Fleetwing, by Black Eagle. Second dam Fanny, by a son of Montauk, by Cassius M. Clay. 


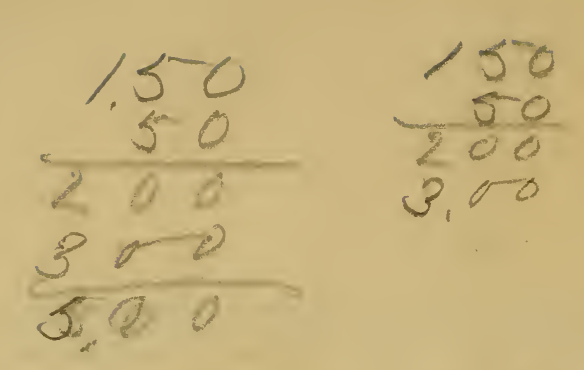

